\title{
Perancangan Sistem Pengendalian Dokumen Pt. Lotte Mart Whole Sale Serang Menggunakan Codeigniter
}

\author{
${ }^{1}$ Thoha Nurhadiyan, M.Kom, ${ }^{2}$ Edy Junaedi S.Kom \\ ${ }^{1,2}$ Jurusan Informatika, Fakultas Teknologi Informasi, Universitas Serang Raya \\ Jl. Raya Serang - Cilegon Km. 05 (Taman Drangong), Serang - Banten \\ Email: ' thoha.nurhadiyan@gmail.com,.2Djunaedy10@gmail.com
}

\begin{abstract}
Abstrak - PT. Lotte Mart Wholesale adalah sebuah perusahaan nomor 5 (lima) terbesar di Korea Selatan, berpengalaman dalam mengoperasikan dunia Retail. Salah satu cabang PT. Lotte Mart Whole Sale yaitu berada di kota Serang yang bernama PT. Lotte Mart Whole Sale Serang. Komputer yang ada di PT. Lotte Mart Whole Sale Serang tidak hanya digunakan sebagai alat pemrosesan data tetapi juga berfungsi sebagai alat pendukung pengambilan keputusan. Salah satu kendala yang terjadi pada PT. Lotte Mart Whole Sale Serang yaitu Administration Logistic Centre (ALC) sering mengalami kendala dalam mendistribusikan dokumen. Karena saat ALC membagikan dokumen kepada Departemen terkait, terkadang pimpinan Departemen tersebut tidak berada ditempat. Selain itu, penyimpanan dokumen pada komputer terlalu rentan terhadap kehilangan dokumen yang diakibatkan oleh virus ataupun kerusakan pada komputer. Sistem pengendalian dokumen yang dibangun menggunakan framework CodeIgniter, pemodelan Unified Modeling Language(UML) sebagai alat untuk menggambarkan model sistem, serta menggunakan Entity Relationship Diagram (ERD). Sistem yang dibangun dapat memberikan kemudahan bagi ALC dalam membuat pengajuan dokumen dan mendistribusikan dokumen kepada departemen terkait dan menjaga keamanan dokumen dari serangan virus atau kerusakan komputer.
\end{abstract}

Kata Kunci : CodeIgniter,Sistem Pengendalian Dokumen, Dokumen, Sistem Informasi

\section{PENDAHULUAN}

PT. Lotte Mart Wholesale adalah sebuah perusahaan nomor 5 (lima) terbesar di Korea Selatan, berpengalaman dalam mengoperasikan dunia Retail. Impian management Lotte Group adalah menjadikan Lotte perusahaan Retail nomor 1 (satu) di Asia.

Komputer yang ada di PT. Lotte Mart Whole Sale Serang tidak hanya digunakan sebagai alat pemrosesan data tetapi juga berfungsi sebagai alat pendukung pengambilan keputusan. Kemajuan teknologi khususnya teknologi informasi, dimana informasi tersebut tentu saja tidak bisa diserap dengan hanya mengandalkan perangkat-perangkat yang masih manual. Maka dari itu, kegunaan komputer sangatlah penting dalam memberikan solusi dan merupakan alat bantu yang cukup baik dalam memperbaiki sistem yang belum optimal. Perkembangan teknologi informasi terus berkembang sesuai dengan kebutuhan dan kegiatan organisasi dalam menghadapi persaingan yang begitu ketat.

Begitu pula dengan penjamin mutu, penjaminan mutu adalah proses penetapan dan pemenuhan standar mutu pengelolaan secara konsisten dan berkelanjutan sehingga konsumen, produsen dan pihak lain yang berkepentingan memperoleh kepuasaan. PT. Lotte
Mart Whole Sale Serang memiliki beberapa departemen, PT. Lotte Mart mempercayakan peningkatan mutu tersebut kepada departemen ALC (Administration Logistic Centre). ALC melaksanakan pengauditan internal kepada setiap departemen. ALC (Administration Logistic Centre) yang bertanggung jawab terhadap administrasi sistem dan pengendalian sistem. Dalam hal ini, pengendalian dokumen yang melakukan kontrol setiap dokumen yang akan didistribusikan dan akan dilakukan pemeriksaan menyangkut isi dari dokumen tersebut adalah departemen ALC (Administration Logistic Centre).

Dalam melakukan kegiatannya, ALC sering mengalami kendala dalam pendistribusian dokumen. Karena sering terjadinya kehilangan dokumen pada departemen terkait. Karena dokumen yang telah diberikan oleh ALC tertumpuk dengan berkas lainnya, sehingga ALC harus mendsitribusi ulang dokumen tersebut. Untuk meminimalisir permasalahan tersebut, maka diperlukan adanya suatu sistem pengendalian dokumen yang tepat. Pengendalian dokumen adalah menerbitkan, mendistribusikan, merevisi, mengendalikan dan memelihara dokumen, kemudian memusnahkan dokumen yang dinyatakan tidak berlaku atau yang telah melampaui masa simpan. Pengendalian dokumen 
sangat dibutuhkan oleh perusahaan, karena dapat membantu Departemen ALC dalam pemeliharaan dan penerbitan dokumen. Hal inilah yang melandasi penulis untuk mengambil judul "Perancangan Sistem Pengendalian Dokumen Pada PT Lotte Mart Wholesale Serang Berbasis Web dan Framework CodeIgniter".

\section{Dasar Teori}

\subsection{Tinjauan Penelitian}

Immanuel Pandiangan. 2012. "Rekayasa Perangkat Lunak Sistem Manajemen Konten Menggunakan Framework CodeIgniter".

Penelitian ini membahas tentang penerapan suatu sistem manajemen konten yang dapat meminimalkan penggunaan pemrograman web dengan kerangka CodeIgniter sebagai salah satu kerangka kerja yang paling banyak didokumentasikan sehingga banyak orang yang mampu membuat, mengelola dan memelihara situs web secara independen tanpa perlu memiliki pengetahuan mendalam mengenai bahasa pemrograman web. Dalam penelitian ini terdapat masalah ketika menciptakan sebuah situs web, yaitu tentang pembuatan situs web yang memerlukan waktu cukup lama dan penyediaan biaya yang cukup besar apabila harus mempekerjakan seorang webmaster. Berdasarkan masalah tersebut, peneliti membuat sistem manajemen konten untuk menyederhanakan pembuatan web dengan menyediakan backend yang mudah untuk dipahami oleh orang-orang yang tidak memiliki pengetahuan dalam pemrograman web dan membantu semua kalangan masyarakat yang ingin membuat situs web pribadi atau kelompok yang memiliki anggaran yang kurang memadai untuk mempekerjakan seorang webmaster.

Afwima Rohmana, 2013. "Perancangan Website ECommerce Guna Membangun Sistem Layanan Informasi Bisnis Indekost Dengan Menggunakan CodeIgniter."

Pembahasan pada penelitian ini yaitu tentang perancangan website e-commerce guna membangun sistem layanan informasi bisnis indekost dengan menggunakan framework codeigniter. Pada penelitian ini, peneliti membuat sebuah sistem informasi yang dapat membantu para mahasiswa untuk menemukan rumah indekost yang sesuai keinginan dan membantu pemilik indekost dalam mengiklankan lokasi rumah indekost. Dalam perancangan sistem ini menggunakan sebuah kerangka kerja yaitu codeigniter yang sudah banyak dipakai dalam pengembangan website, ringan dan cepat dalam membangun pemrograman website dinamis. Pengembangan sistem ini menggunakan sistem SDLC (System Development Life Cycle) yang meliputi perencanaan sistem, analisa kebutuhan sistem, desain sistem, implementasi sistem, dan pengujian sistem. Perancangan sistem ini didukung dengan software adobe Dreamweaver CS5, buku panduan untuk pengembangan sistem, dan webhosting yang mendukung dalam meng-upload website ini.

Sophan Sophian, 2014. "Pengimplementasian Dan Perancangan Sistem Informasi Penjualan Dan Pengendalian Stok Barang Pada Toko Swastika Servis (SS) Bangunan Dengan Menggunakan Bahasa Pemrograman Visual Basic 6.0 Didukung Dengan Database MySQL."

Pembahasan pada penelitian ini yaitu tentang perancangan sistem informasi penjualan dan pengendalian stok barang pada Toko Swastika Servis (SS) Bangunan. Dalam penelitian ini terdapat masalah terhadap pemeliharaan dokumen penjualan dan persediaan stok barang yang masih menggunakan sistem manual. Atas dasar permasalahan tersebut, peneliti membuat suatu sistem yang tepat dan jelas agar mampu meningkatkan produktifitas Toko Swatika Servis (SS) Bangunan dan membantu pegawai dalam membuat pengolahan data secara terkomputerisasi agar dapat meminimalisir terjadinya kesalahan dan mampu menjamin keamanan dan keselamatan data.

Hustinawati, 2014. "Performance Analysis Framework CodeIgniter And CakePHP in Website Creation.".Pembahasan pada penelitian ini yaitu tentang perbandingan antara framework codeigniter dan framework cakePHP yang diimplementasikan dengan pembuatan website untuk menampilkan data dari sebuah database. Landasan analisis ini dilakukan berdasarkan enam faktor yaitu dalam hal kinerja, arsitektur, fitur-fitur yang tersedia, penerapan implementasi Ajax, ORM (Object Relational Mapping), dan kapasitas masing-masing kerangka kerja. Sehingga kedua jenis framework PHP tersebut dapat diketahui manfaat dan kekurangannya.

Rendy Andriyanto, 2016. "Sistem Manajemen Dokumen Dengan Metode Framework For The Applications Of System Technology (FAST)."

Pembahasan pada penelitian ini yaitu tentang sistem manajemen dokumen dengan metode Framework for the Applications of System Technology (FAST). Permasalahan dalam penelitian ini yaitu penomoran dokumen dan pendistribusian dokumen saat ini masih menggunakan sistem manual. Berdasarkan masalah tersebut, peneliti membuat sistem manajemen dokumen untuk membantu penomoran dokumen dan pendistribusian dokumen secara terkomputerisasi agar dapat meminimalisir kesalahan pada penomoran dokumen. Metode Framework for the Applications of System Technology (FAST) adalah salah satu metode pengembangan sistem informasi dengan urutan langkahnya yaitu lingkup definisi, analisa permasalahan, analisa kebutuhan, analisa keputusan, desain logis, desain fisik dan integrasi, membangun sistem dan pengujian sistem. 
Metta Anggraini, 2016. "Rancang Bangun Sistem Informasi Pengendalian Dokumen Dan AMI (Audit Mutu Internal) Pada BPM Kampus MDP." Pembahasan pada penelitian ini yaitu kampus MDP memiliki kendala dalam melakukan pendistribusian dokumen yang sering tidak tepat waktu dan sering terjadinya kehilangan dokumen karena dokumen tersebut diletakkan diatas meja atau tertumpuk dengan dokumen lain. Serta pihak BPM sering kesulitan dalam menghitung dan merekap hasil temuan audit. Berdasarkan masalah tersebut, peneliti merancang sebuah sistem informasi pengendalian dokumen dan Audit Mutu Internal (AMI) pada BPM Kampus MDP berbasis website menggunakan bahasa pemrograman PHP serta MySQL sebagai basis datanya. Metode yang digunakan untuk pengembangan sistem ini adalah metode iterasi yang meliputi tahap analisa, tahap desain, tahap code dan tahap implementasi

\subsection{Dasar Teori}

\subsubsection{Pengertian Pengendalian Dokumen}

Pengendalian dokumen adalah menerbitkan, mendistribusikan, merevisi, mengendalikan dan memelihara dokumen, kemudian memusnahkan dokumen yang dinyatakan tidak berlaku atau yang telah melampaui masa simpan. Pengendalian dokumen sangat dibutuhkan oleh perusahaan, karena dapat membantu sebuah organisasi atau perusahaan dalam pemeliharaan dan penerbitan dokumen. Tujuan pengendalian dokumen adalah sebagai acuan dalam penerapan langkah-langkah untuk mengendalikan seluruh dokumen, agar dokumen sistem manajemen mutu yang dipergunakan adalah dokumen yang tepat dan benar, mudah diidentifikasi, mudah digunakan dan untuk menghindari penggunaan dokumen yang sudah tidak berlaku.

\subsubsection{Pengertian CodeIgniter}

CodeIgniter (CI) adalah framework pengembangan aplikasi (Application Development Framework) dengan menggunakan PHP, suatu kerangka untuk bekerja atau membuat program dengan menggunakan PHP yang lebih sistematis. Pemrogram tidak perlu membuat dari program dari awal (from scratch), karena CI menyediakan sekumpulan librari yang banyak diperlukan untuk menyelesaikan pekerjaan umum, dengan menggunakan antarmuka dan struktur logika yang sederhana untuk mengakses librarinya. Pemrogram dapat memfokuskan diri pada kode yang harus dibuat untuk menyelesaikan suatu pekerjaan.

Framework CodeIgniter merupakan framework yang memiliki dokumentasi yang jelas dan lengkap, yang memudahkan pengembang untuk mempelajari dengan mudah. Pendekatan dari CI sangatlah mudah, dari membuat sekedar tulisan sampai dengan yang kompleks dapat didekati dengan mudah.

\subsubsection{Pengertian Teknik MVC (Model, View, Controller)}

Teknik MVC (Model, View, Controller) merupakan teknik pemrograman yang popular saat ini, yang mengharapkan pemrogram secara disiplin untuk membagi program menjadi 3 bagian, yaitu model, view, dan controller.

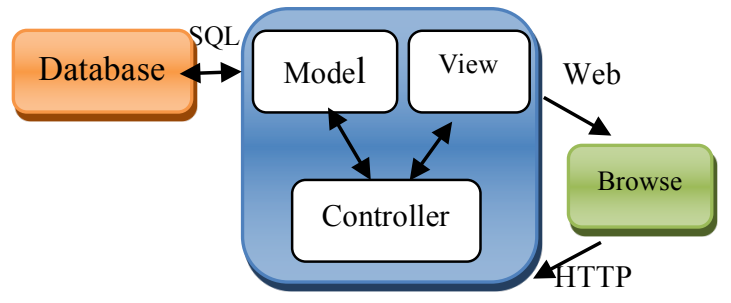

Gambar 2.1 Pola MVC

a. Model

Model adalah bagian dari aplikasi yang mengimplementasi logika untuk domain data aplikasi. Umumnya, model digunakan untuk mengambil data dari database atau menyimpan data ke dalam database. b. View

View adalah komponen untuk menampilkan antarmuka untuk pengguna (user interface) aplikasi. Antarmuka ini dibuat berdasarkan data dari model.

c. Controller

Controller merupakan komponen yang digunakan untuk menangani interaksi pengguna, bekerja dengan model, dan memilih view mana yang digunakan untuk merender data

\subsubsection{Analisa System}

Analisis sistem adalah sistem yang berjalan dengan tujuan untuk mendesain sistem baru yang mentempurnakan sistem lama.

Rincian tujuan dari tahapan sistem analis adalah:

a. Membuat keputusan apabila sistem ini mempunyai masalah atau tidak berfungsi dengan baik dan hasil analisisnya digunakan sebagai dasar untuk memperbaiki sistem.

b. Mengetahui ruang lingkup pekerjaan yang akan ditanganinya.

c. Memahami sistem yang berjalan saat ini.

d. Mengidentifikasikan masalah dan mencari solusinya.

\subsubsection{UML (Unified Modelling Language)}

Unified Modeling Language (UML) adalah bahasa spesifikasi standar untuk mendokumentasikan, menspesifikasikan, dan membangun system. Unified Modeling Language (UML) adalah himpunan struktur dan teknik untuk pemodelan desain program berorientasi objek (OOP) serta aplikasinya. 
UML adalah metodologi untuk mengembangkan sistem OOP dan sekelompok perangkat tool untuk mendukung pengembangan sistem tersebut. UML mulai diperkenalkan oleh Object Management Group, sebuah organisasi yang telah mengembangkan model, teknologi, dan standar OOP sejak tahun 1980-an. Sekarang UML sudah mulai banyak digunakan oleh para praktisi OOP. UML merupakan dasar bagi perangkat (tool) desain berorientasi objek dari IBM. (Herlawati, 2011:1).

UML adalah suatu bahasa yang digunakan untuk menentukan, memvisualisasikan, membangun, dan mendokumentasikan suatu sistem informasi. UML dikembangkan sebagai suatu alat untuk analisis dan desain berorientasi objek oleh Grady Booch, Jim Rumbaugh, dan Ivar Jacobson Namun demikian UML dapat digunakan untuk memahami dan mendokumentasikan setiap sistem informasi. Penggunaan UML dalam industri terus meningkat. Ini merupakan standar terbuka yang menjadikannya sebagai bahasa pemodelan yang umum dalam industri peranti lunak dan pengembangan sistem. Singkatnya Unified Modelling Language (UML) adalah sebuah "bahasa" yang telah menjadi standar dalam industri untuk visualisasi, merancang dan mendokumentasikan sistem piranti lunak. UML menawarkan sebuah standar untuk merancang model sebuah sistem. Sampai era tahun 1990 puluhan metodologi pemodelan berorientasi objek telah bermunculan di dunia. Diantaranya adalah: metodologi booch, metodologi coad, metodologi OOSE, metodologi OMT, metodologi shlaer-mellor, metodologi wirfs-brock, dsb. Masa itu terkenal dengan masa perang metodologi (method war) dalam pendesainan berorientasi objek.

Masing-masing metodologi membawa notasi sendirisendiri, yang mengakibatkan timbul masalah baru apabila kita bekerjasama dengan kelompok/perusahaan lain yang menggunakan metodologi yang berlainan. Dimulai pada bulan Oktober 1994 Booch, Rumbaugh dan Jacobson, yang merupakan tiga tokoh yang boleh dikatan metodologinya banyak digunakan mempelopori usaha untuk penyatuan metodologi pendesainan berorientasi objek. Pada tahun 1995 direlease draft pertama dari UML (versi 0.8). Sejak tahun 1996 pengembangan tersebut dikoordinasikan oleh Object Management Group (OMG). (Herlawati, $2011: 2-3$ ).

\subsubsection{Kerangka Pikir}

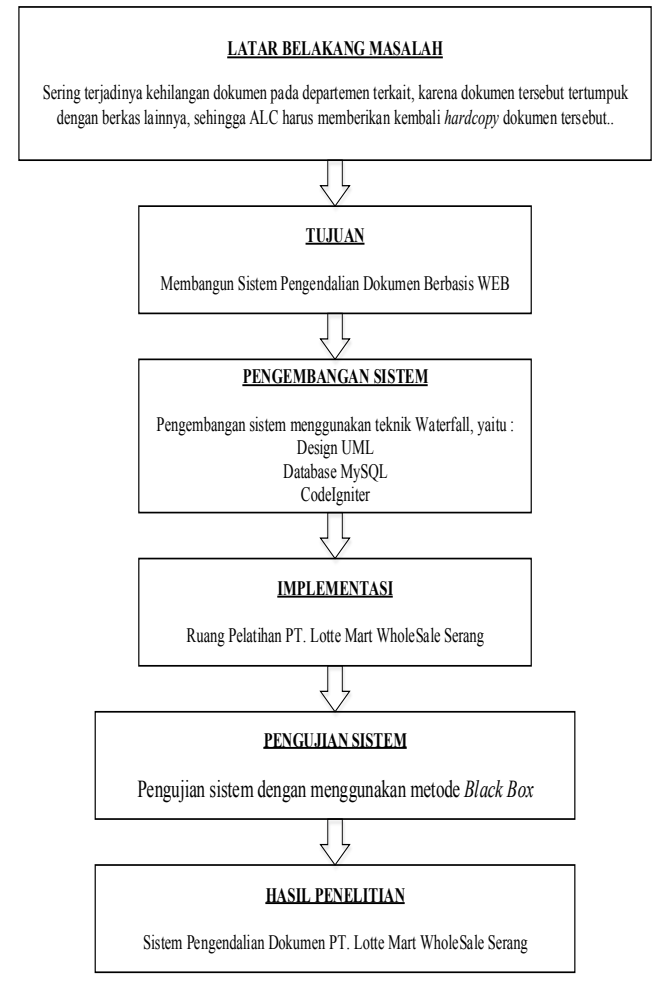

3. PERANCANGAN

3.1. Analisa Proses

Analisa proses digunakan untuk mengalisa proses sistem yang sedang berjalan saat ini. Peneliti akan menguraikan secara umum tentang proses dari sistem pengendalian dokumen pada PT. Lotte Mart Wholesale Serang dengan urutan sebagai berikut :

1) Olah data pengajuan terbaru atau revisi dokumen. Pada proses ini pihak ALC (Administration Logistic Centre) akan melakukan pengajuan dokumen terbaru atau revisi kepada SGM (Store General Manager) untuk ditinjau terlebih dahulu, apakah dokumen tersebut layak untuk di distribusikan atau tidak.

2) Olah data pengajuan dokumen terbaru atau revisi. Pada proses ini SGM (Store General Manager) akan meninjau pengajuan dokumen terbaru atau revisi yang telah diajukan oleh pihak ALC. Jika dokumen tersebut layak untuk didistribusikan, maka pengajuan dokumen terbaru atau revisi akan disetujui dan akan dikembalikan kepada pihak ALC untuk segera didistribusikan kepada departemen terkait. Jika terdapat kesalahan dalam pengajuan dokumen, maka dokumen akan dikembalikan kembali kepada pihak ALC untuk diperbaiki oleh pihak ALC.

3) Olah data informasi pendistribusian dokumen. Pada proses ini, jika pengajuan dokumen terbaru atau revisi telah disetujui oleh SGM (Store General Manager), maka pihak ALC akan segera 
mendistribusikannya kepada departemen terkait agar informasi yang ada didalam dokumen dapat segera dipublikasikan.

Berikut dibawah ini adalah gambaran analisa proses menggunakan flowchart :

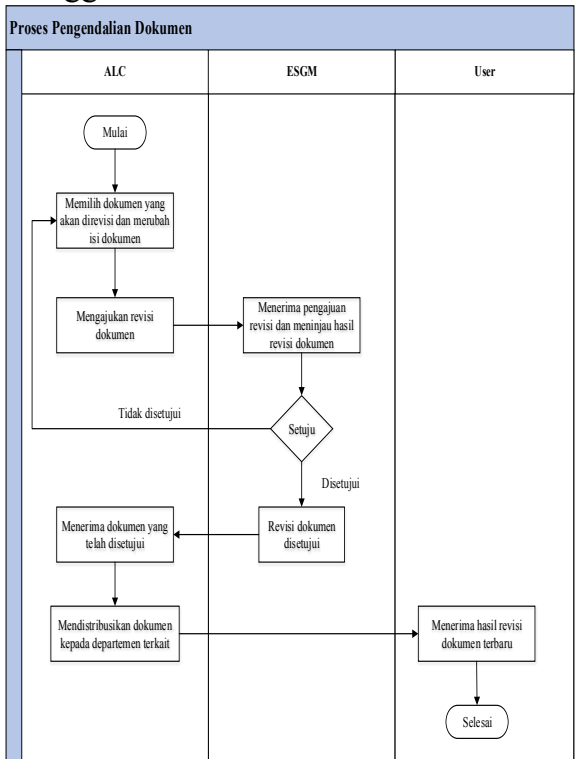

Gambar 3.1 Flowchart Proses Pengendalian Dokumen

\subsection{Perancangan Sistem}

3.2.1. Diagram Use Case

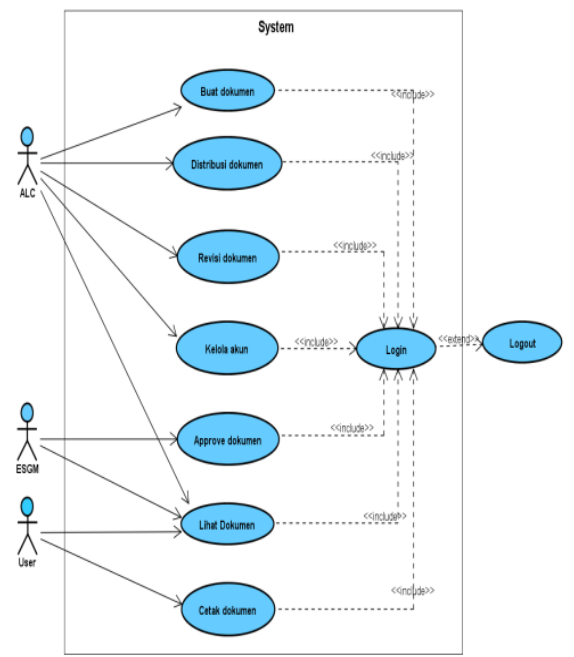

3.2.2. Activity Diagram Buat Documen

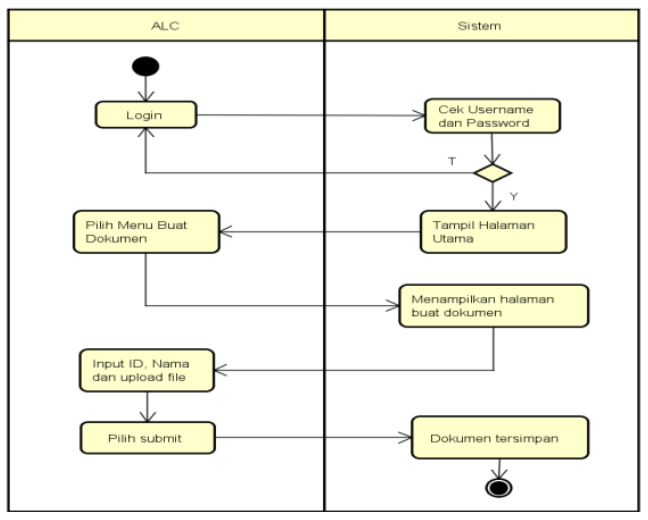

3.2.3. Activity Diagram Distribusi Document

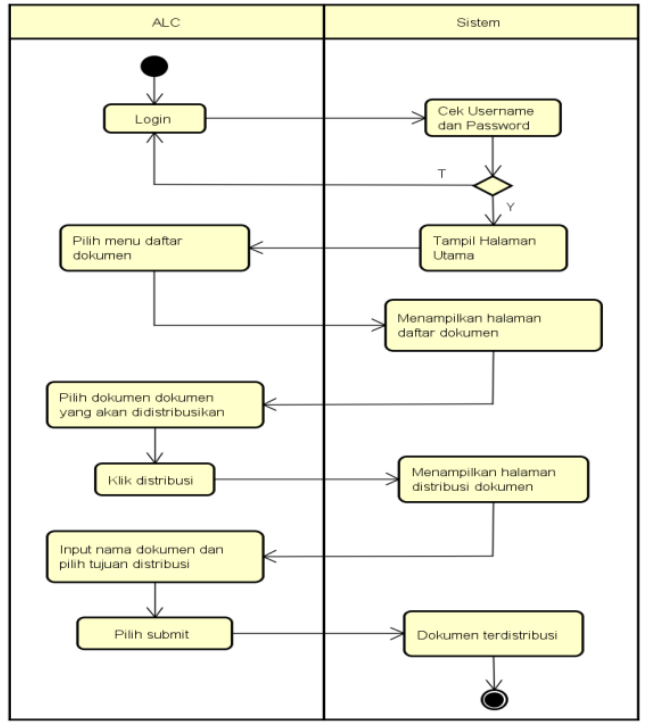

3.2.4. Actifity Diagram Revisi Document

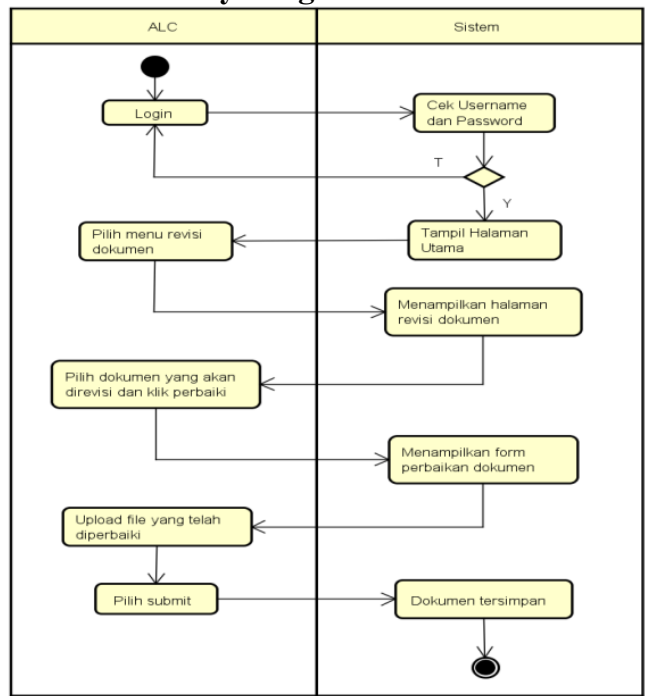




\subsubsection{Actifity Diagram Kelola Akun}

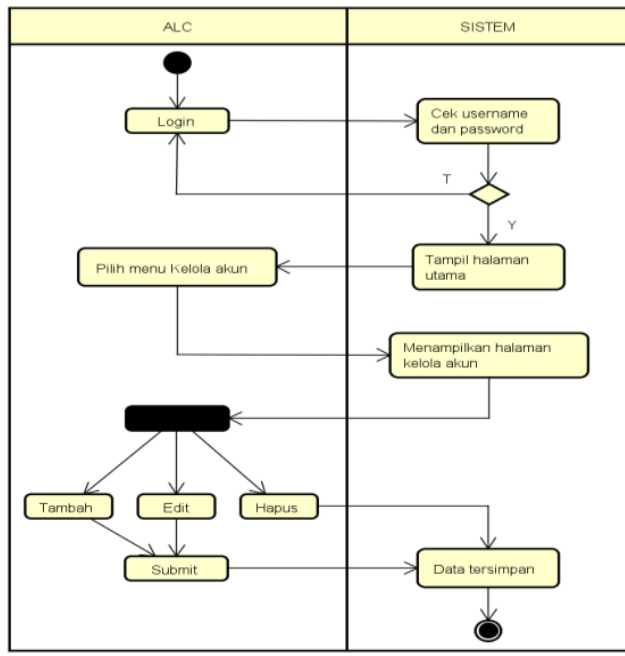

3.2.6. Actifity Diagram Approve Document

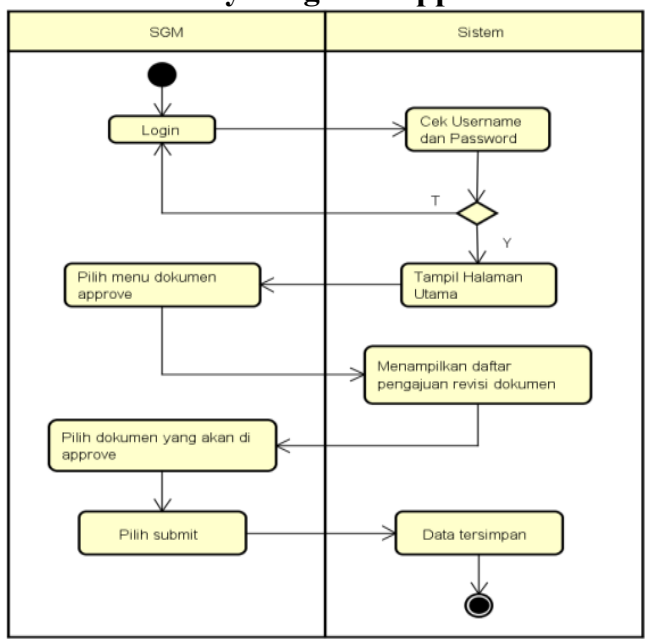

\subsubsection{Actifity Diagram Lihat Document}

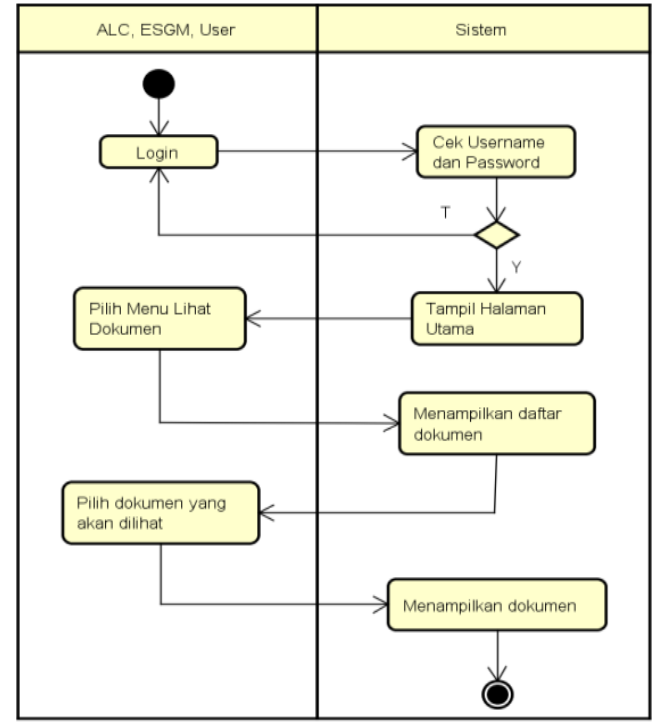

3.2.8. Actifity Diagram Lihat Document

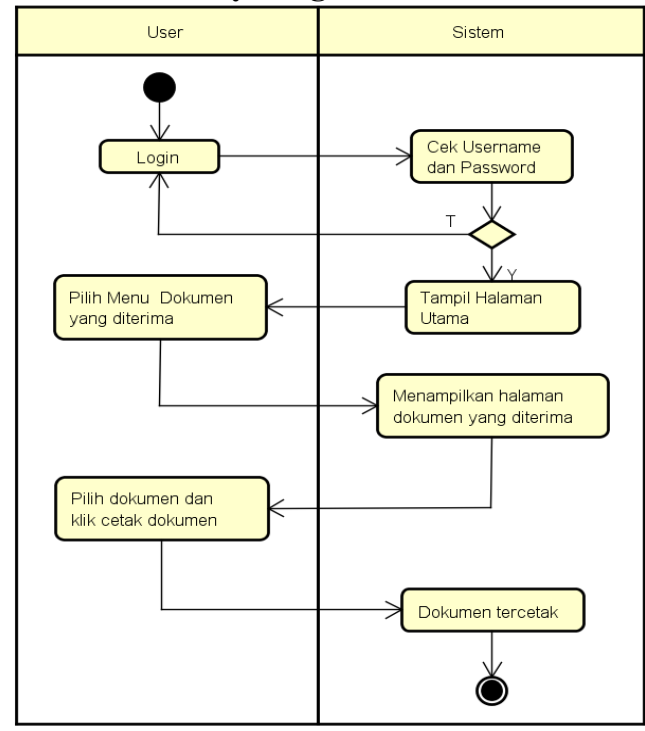

3.2.9. Sequence Diagram Buat Document

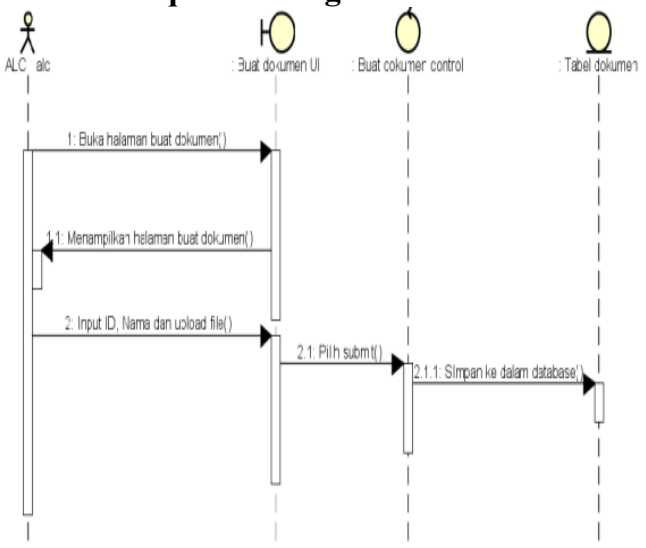




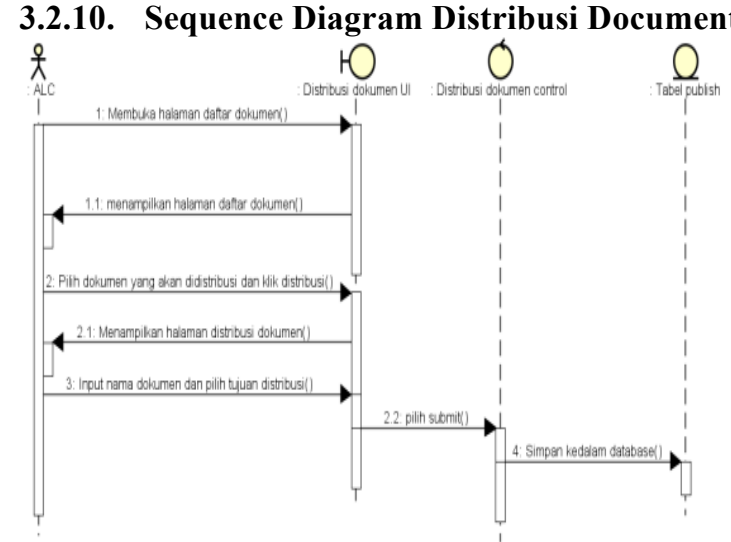

3.2.11. Sequence Diagram Revisi Document

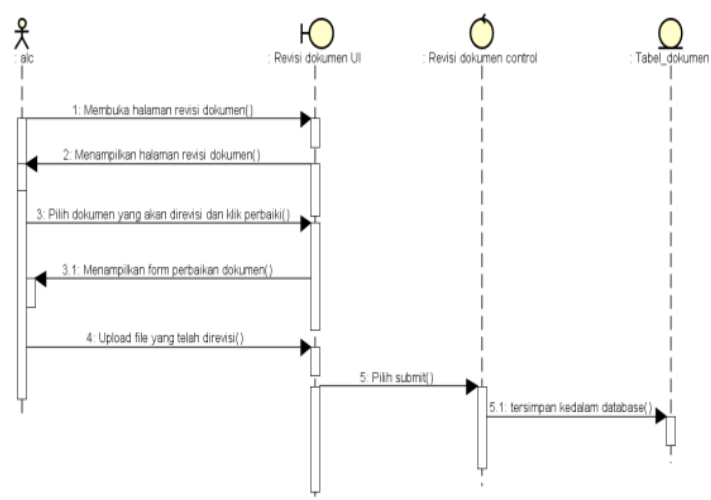

3.2.12. Sequence Diagram Approve Document

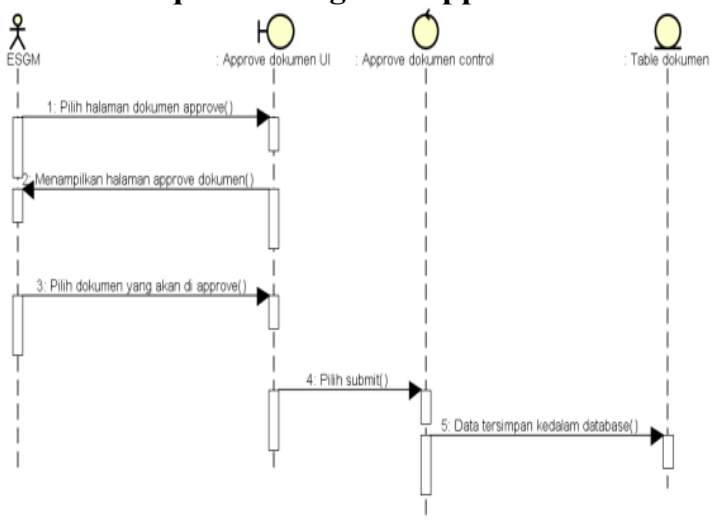

3.2.13. Sequence Diagram Lihat Document

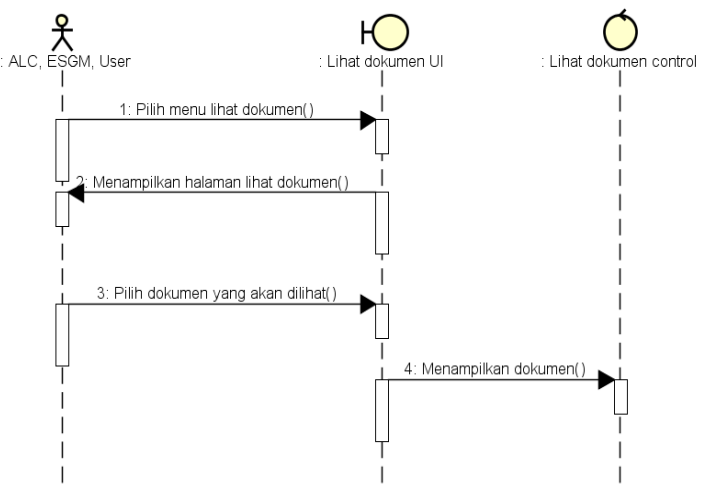

3.2.14. Sequence Diagram Cetak Document

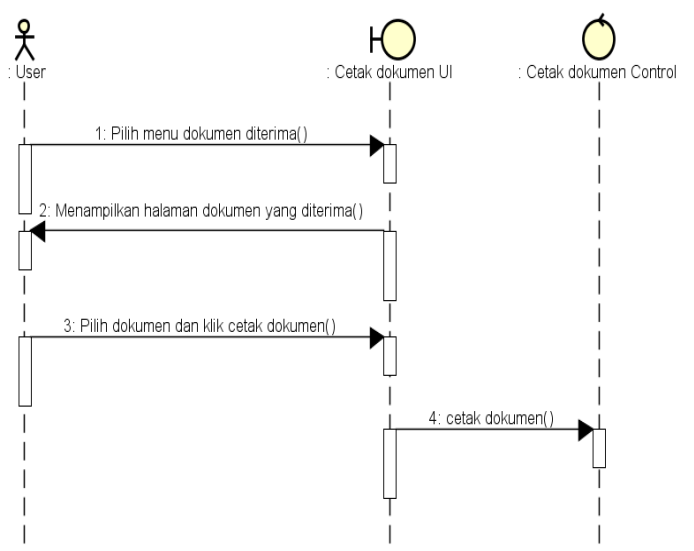

3.2.15. Relasi Antar Tabel
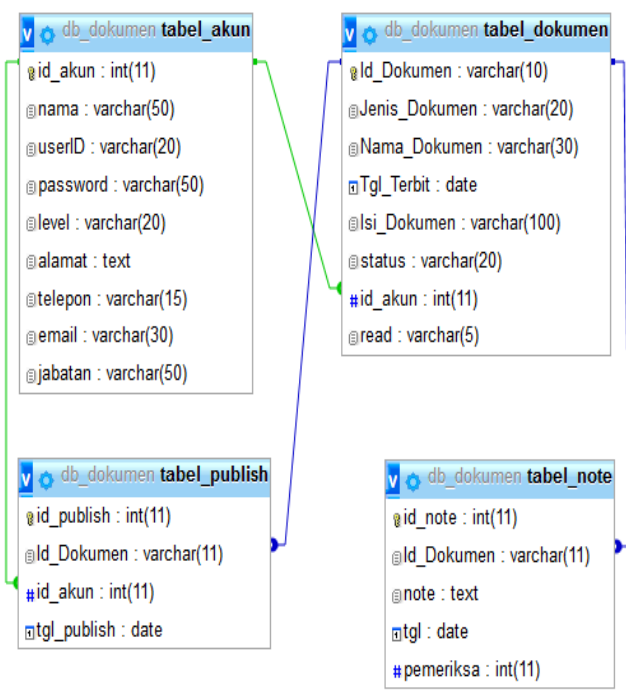

4. Implementasi System

4.1. Implementasi antar muka 4.1.1.Halaman Login 


\section{LOTTE Mart}

\section{wholesale}

Login Ke Doc Control

\section{Username}

Password

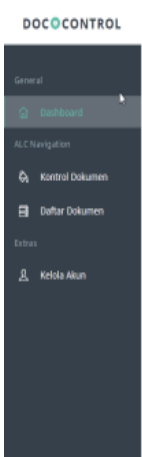

\section{pashboard}

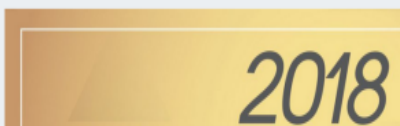

FIGHT TO WIN

AGLE, EXECUTE \& INNOVATE

LOTTEMart | LOTTE Grosir

DOCOCONTROL $\equiv$

Hi, Edvilunaedi

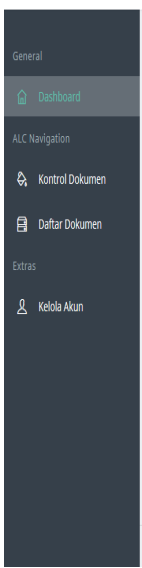

Kontrol Dokumen

Kontrolodolunen! Buat dockumen

ID Dokumen
D-0003

Jenis oolumen

Asset $\quad$.

Nama Dokumen

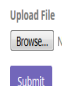

\subsubsection{Halaman Lihat Dokumen}

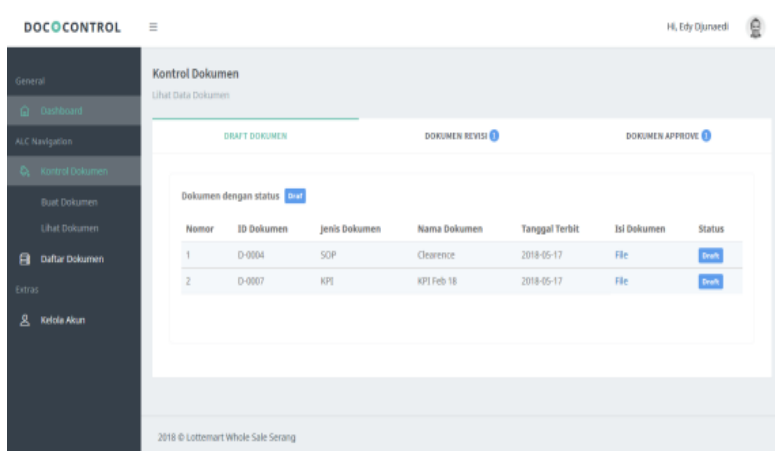

4.1.5.Halaman Documen Revisi
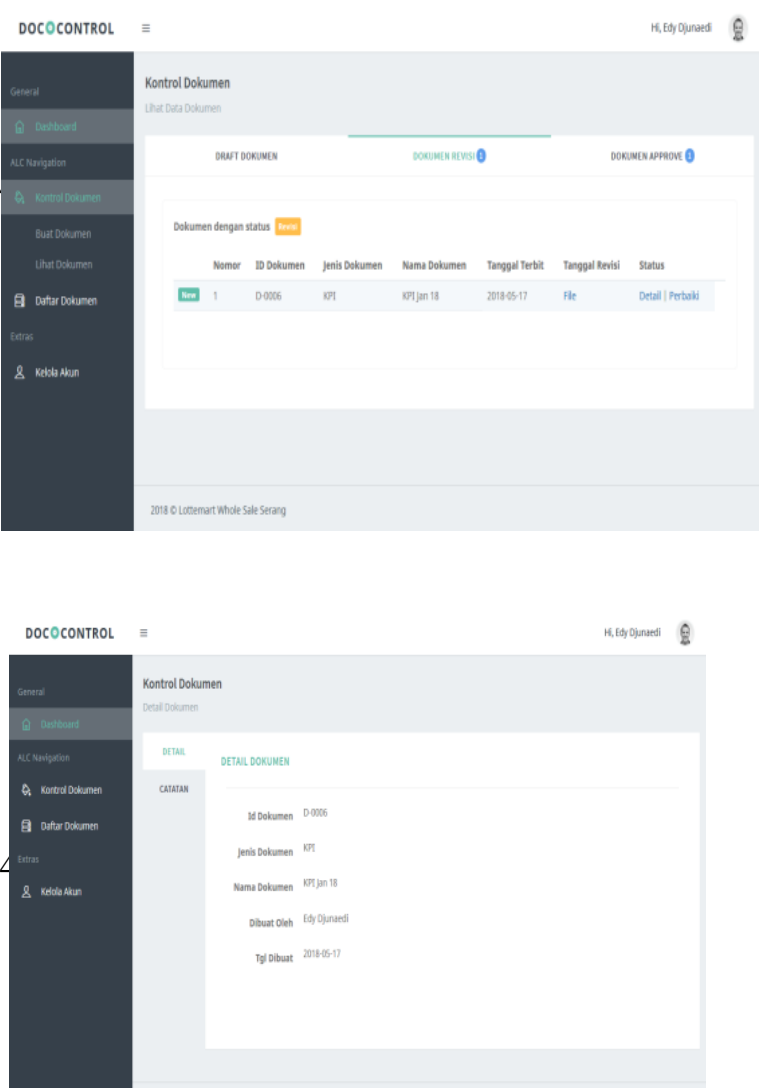

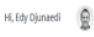
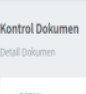

DETL DOKUNEM

aim

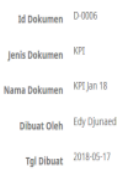

DOCOCONTROL
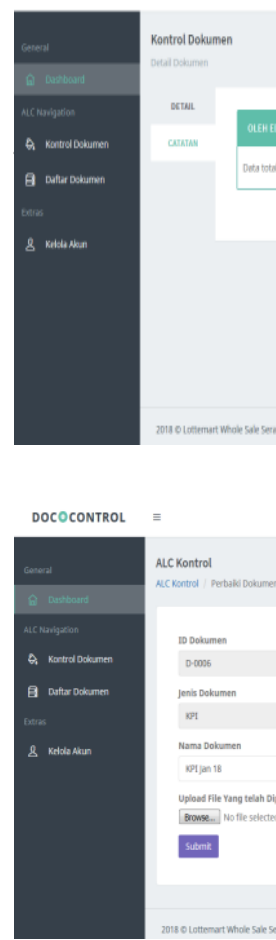

e

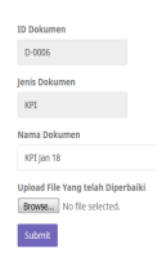




\subsubsection{Halaman Document Approve}

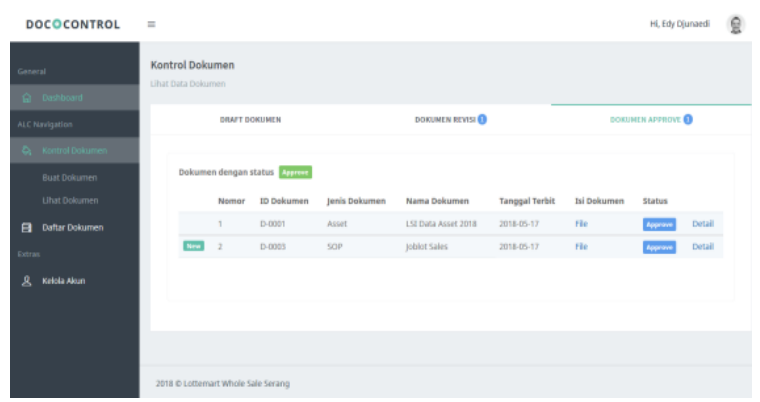

\subsubsection{Halaman Daftar Document}

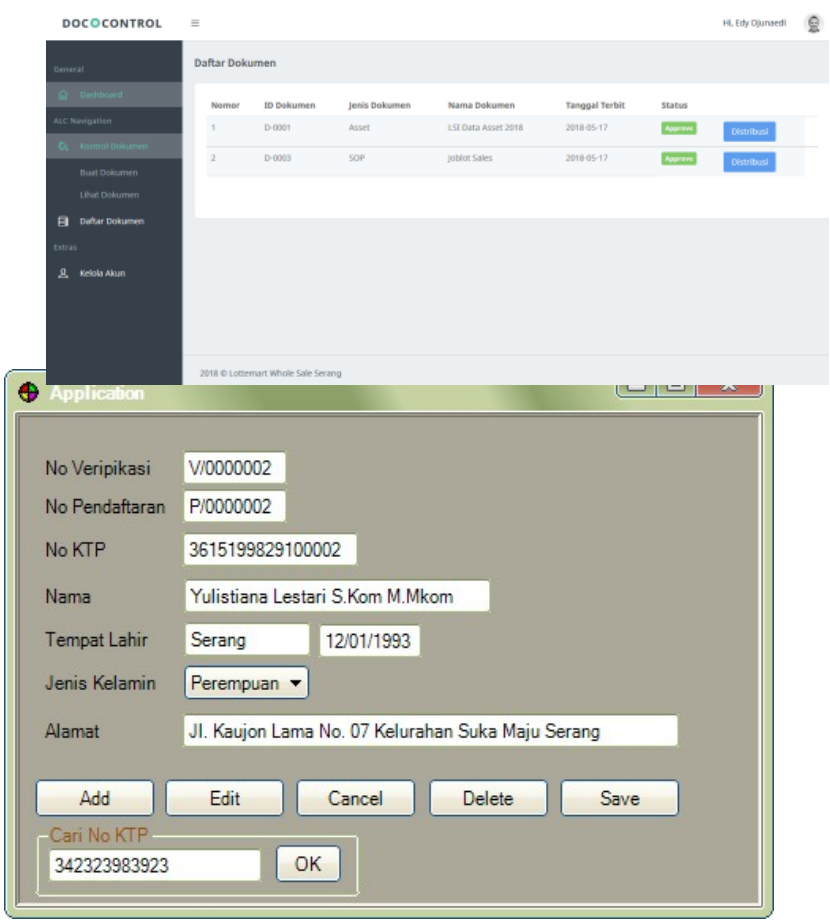

\subsection{Pengujian System}

\begin{tabular}{|l|l|l|l|}
\hline $\begin{array}{l}\text { Penguji } \\
\text { Sistem }\end{array}$ & $\begin{array}{l}\text { Yang } \\
\text { Diharapkan }\end{array}$ & Hasil & Kesimpulan \\
\hline $\begin{array}{l}\text { Agung } \\
\text { Dermawan }\end{array}$ & $\begin{array}{l}\text { Berhasil } \\
\text { masuk } \\
\text { kedalam } \\
\text { sistem dan } \\
\text { masuk ke } \\
\text { halaman }\end{array}$ & $\begin{array}{l}\text { Data login } \\
\text { benar, } \\
\text { masuk ke } \\
\text { halaman }\end{array}$ & Sesuai \\
& ALC. & \\
& ALC. & & \\
\cline { 2 - 4 } & $\begin{array}{l}\text { Berhasil } \\
\text { masuk } \\
\text { kedalam }\end{array}$ & $\begin{array}{l}\text { Data login } \\
\text { benar, } \\
\text { masuk ke } \\
\text { halaman }\end{array}$ & Sesuai \\
& $\begin{array}{l}\text { sistem dan } \\
\text { masuk ke } \\
\text { halaman }\end{array}$ & SGM. & \\
& SGM. & & \\
& &
\end{tabular}

\begin{tabular}{|l|l|l|l|}
\hline & $\begin{array}{l}\text { Berhasil } \\
\text { masuk } \\
\text { kedalam }\end{array}$ & $\begin{array}{l}\text { Data login } \\
\text { benar, } \\
\text { masuk ke }\end{array}$ & \\
& sistem dan & halaman & \\
masuk ke & User. & \\
& halaman & & \\
& User. & & \\
\hline & & & \\
\hline & & & \\
\hline
\end{tabular}

Berdasarkan hasil pengujian dengan kasus sample uji di atas dapat ditarik kesimpulan bahwa sistem dapat berjalan dengan baik dan sesuai kebutuhannya dan juga dapat menghasilkan output yang diharapkan, walaupun terbatas hanya pada pengujian yang minimal, namun diharapkan pengujian yang ditampilkan diatas sudah dapat mewakili pengujian fungsionalitas yang lainnya.

\section{KESIMPULAN DAN SARAN}

\subsection{Kesimpulan}

Berdasarkan hasil penelitian dan pembahasan mengenai Perancangan Sistem Pengendalian Dokumen Pada PT. Lotte Mart Whole Sale Serang Berbasis Web dan Framework Codeigniter yang telah di analisis, dirancang, diimplementasi dan dilakukan pengujian, maka dapat diambil kesimpulan sebagai berikut :

1. Sistem yang dibangun dapat memberikan sarana sesuai yang diharapkan yaitu dapat memberikan kemudahan bagi ALC (Administration Logistic Centre) dalam mendistribusikan dokumen.

2. Sistem yang dibangun dapat memberikan sarana sesuai yang diharapkan yaitu dapat meminimalisir terjadinya kehilangan dokumen pada departemen terkait.

\subsection{Saran}

Berdasarkan kesimpulan yang telah diuraikan diatas, maka saran yang diharapkan penulis untuk pengembangan sistem pengendalian dokumen ini selanjutnya adalah sebagai berikut :

1. Untuk pengembangan lebih lanjut perangkat lunak sistem pengendalian dokumen ini masih perlu adanya penambahan fungsi notifikasi dokumen masuk melalui pesan singkat agar lebih memudahkan user dalam mengetahui dokumen terbaru yang didistribusikan oleh ALC.

2. Perlu adanya pengembangan sistem yang lebih besar untuk mencakup seluruh PT. Lotte Mart yang ada di Indonesia, agar penyimpanan semua dokumen-dokumen penting PT. Lotte Mart Indonesia lebih terjaga keamanannya.

\section{DAFTAR PUSTAKA}

Andriayanto, Rendy. (2016). "Sistem Manajemen Dokumen Dengan Metode Framework For The Applications Of System Technology (FAST)." Jurnal Ilmiah ST3 Telkom Purwokerto. Vol.2. No. (96). 978-979. 
Elvin dan Metta Anggraini. (2016). "Rancang Bangun Sistem Informasi Pengendalian Dokumen Dan AMI Pada BPM Kampus MDP.” Jurnal Sistem Informasi STMIK MDP Palembang.

Hustinawati, at al. (2014). "Performance Analysis Framework CodeIgniter and CakePHP in Website Creation." International Journal of Computer Applications. Vol. 94. No.(20). 0975-8887.

Pandiangan, Immanuel. (2012). "Rekayasa Perangkat Lunak Sistem Manajemen Konten Menggunakan Framework CodeIgniter." Jurnal Computech \& Bisnis. Vol. 6. No. (2). 75-81.

Raharjo, Budi. et all. (2014). Modul Pemrograman Web HTML, PHP Dan MySQL Revisi Kedua. Bandung: Modula Bandung.

Rohmana, Afwima. (2013). "Perancangan Website ECommerce Guna Membangun Sistem Layanan Informasi Bisnis Indekost Dengan Menggunakan CodeIgniter." Program Studi Teknik Industri Fakultas Teknik Universitas Brawijaya. Vol. 1. No. (2). 241-252.
S. Rosa A. dan M. Shalahuddin. (2016). Rekayasa Perangkat Lunak Terstruktur dan Berorientasi Objek. Bandung: Informastika Bandung.

Sidik, Betha. (2012). Framework CodeIgniter (Menggunakan Framework CodeIgniter 2.x untuk Memudahkan Pengembangan Pemrograman Aplikasi WEB dengan PHP 5). Bandung: Informatika Bandung.

Sophian, Sophan. (2014). "Pengimplementasian Dan Perancangan Sistem Informasi Penjualan Dan Pengendalian Stok Barang Pada Toko Swastika Servis (SS) Bangunan Dengan Menggunakan Bahasa Pemrograman Visual Basic 6.0 Didukung Dengan Database MySQL." Jurnal Momentum. Vol. 16. No. (2). 1693-752X.

ST, Yuni Sugiarti. (2011). Metode Penelitian Dibidang Komputer dan Teknologi Informasi. Banten: Dinas Pendidikan Provinsi Banten.

Sudaryono, Dr. 2015. Metodologi Riset di Bidang TI (Panduan Praktis, Teori dan Contoh Kasus). Yogyakarta: Andi. 